\title{
Politics of Testing and Assessment
}

\author{
SALAH TROUDI
}

\section{Framing the Issue}

Given the major role that the assessment of English as foreign language (EFL) and English as second language (ESL) plays in the educational experiences and lives of students around the world, TESOL practitioners and theoreticians have no choice but to ensure that assessment is solid, reliable, and unquestionable. To guarantee the quality of assessment procedures, TESOL professionals have for long relied on the tools, language, and techniques of the scientific approach to research. At their disposal are mechanisms, procedures, and terminology that have been employed for decades, in an attempt to guarantee the validity, reliability, and above all the neutrality of the assessment procedures that measure students' linguistic proficiency (Brown, 1996). Driven by the discourses of accountability, efficiency, objectivity, and accuracy, the field of language assessment has succeeded to a large extent in establishing a discourse of unquestioned credibility at theoretical and practical levels (Brown \& Hudson, 1998). Internationally renowned high-stakes language tests such as the TOEFL, IELTS, or the Michigan tests have long surpassed their original function of language-proficiency tests and serve as gatekeepers at established educational institutions around the world, which deploy several activities such as research, training of testers, marketization, and publication. Moreover, the content of these tests has influenced the curricular goals and the content of many language-preparation programs, as students have to take them for entry and exit purposes. While originally the tests were solely for testing the language proficiency of prospective students and their suitability for a university in the United States or Britain, this use has now been expanded to cover multiple educational, employment, and even immigration purposes.

The dominance of the scientific approach to testing and the power of the major standardized tests have not stopped theoreticians and practitioners from questioning this power and the assumed neutrality, objectivity, and fairness of the tests (Shohamy, 2001; Au, 2009; Kunan, 2010).

The use of the phrase "politics of assessment" implies that assessment in general and language assessment in particular are informed by such factors as ideologies, political and economic agendas, educational considerations, societal elements, 
issues of power, hierarchical structures, and teachers' roles. This entry will address the power of high-stakes tests and the teachers' knowledge of testing from a critical perspective. Practical implications for TESOL professionals will be outlined.

\section{Making the Case}

The aura of scientificity and the technical jargon long associated with the domain of assessment-which, in the literature, is often used interchangeably with testing - have often led TESOL teachers to associate testing with a special group of experts who have monopoly over knowledge in this field. McNamara argues that the practice of testing is often little understood and that "this process, which so often affects our lives, becomes the province of experts and we become dependent on them." This expertise, he adds, is "seen as remote and obscure, and the tests they produce are typically associated in us with feelings of anxiety and powerlessness" (McNamara, 2000, p. 3). However, it should also be mentioned in this context that there has been a change in the approach to research on testing and that the scientific research methodology and its jargon are no longer the only way of studying or discussing testing. Over the past years the humanistic approach has had an effect on testing that has resulted in the questioning of the efficacy and appropriateness of methods such as paperand-pencil language tests with an associated, fixed response and a multiplechoice format. This approach has paved the way for performance-based tests, where the focus is on assessing acts of communication most commonly used in assessing writing and speaking. Perhaps the most salient effect of the humanistic approach is that the movement of alternative assessment has become part of the accepted discourse and literature on testing in schools and language programs. This movement, along with the process of self-assessment, is a clear indication that assessment has made steady steps away from the hegemony of the psychometric approach. This recent development of non-psychometric approaches to research in assessment has made it possible to investigate informal and formative classroom-based testing through qualitative methods. Some studies have looked at learners' experiences of assessment, while others investigated the nature of discourses and identities adopted by learners during assessment procedures (Leung \& Mohan, 2004).

In an attempt to address major issues and challenges met by teachers in the area of assessment literacy, Coombe, Troudi, and Al-Hamly (2012) argue that, "for those teachers who are not involved in setting tests or assessments for their students, they [the teachers] feel that a gap between teaching and testing is in evidence" (p. 21). Research in assessment and EFL/ESL teacher education programs have not made major steps to redress this gap, and the issue of teacher assessment literacy remains a low priority (Cheng, Rogers, \& Wang, 2008). In recent publications on assessment literacy, this concept is often presented as the ability of the teacher to understand the main principles of sound assessment (Popham, 2004). Knowledge of critical issues and political agendas in language assessment is still not part of 
what constitutes a language teacher's assessment knowledge. In a research study conducted in the United Arab Emirates and Kuwait, Troudi, Coombe, and Al-Hamly (2009) report that EFL teachers were marginalized from the process of developing tests in foundations programs. None of the participants in the study mentioned critical language assessment or issues of power and equality when asked about their own views on assessment. The teachers' main concern was with issues of format, validity, and reliability of the assessment procedures and related technical elements.

Given the multidimensional and important role that testing plays in the lives of students and in society at large, EFL teacher education programs need to include elements of critical testing literacy in teacher preparation curricula. The next section will discuss the pedagogical implications of an approach to teacher literacy in assessment.

\section{Pedagogical Implications}

A balance between the different elements that constitute an EFL/ESL teacher's assessment literacy is needed if practicing teachers are to develop a well-rounded approach to testing pedagogy. An EFL teacher needs to be introduced to the theoretical, developmental, technical, and critical elements of assessment. For this to become a reality, educators themselves need to acknowledge that issues of ethics, power, political manipulation, economic considerations, inequality and social fairness, and sociocultural contexts need to be added to the curriculum, both when preparing future teachers and during in-service training.

At the theoretical level, teachers need to be introduced to the links between a particular learning theory and an assessment approach and to the idea that there must be compatibility between the two. If students are taught English in a taskbased and social interactionist approach informed by a sociocultural theory to learning, then assessing their English language skills through a test of discrete items that uses a multiple-choice format with close-ended questions would be pedagogically inappropriate. In this case a project-based approach as an element of alternative assessment would be more compatible with the teaching approach. On the other hand, a discrete-item test would fit a teacher-centered classroom methodology.

EFL/ESL Teachers also need to become familiar with theories such as the classical testing theory (CTT) and the criterion-referenced testing (CRT) theory (Brown, 2005). CTT has informed the developments of standardized tests of proficiency and placement and is useful at institutional levels where decisions have to be made about students' levels of proficiency. Established principles and technical terms such as the different kinds of validity, reliability, and item-analysis procedures fit under CTT. For the analysis of classroom-based tests that are also based on criteria, CRT is useful and the concept of dependability would be appropriate. Here the primary focus for the teacher is whether the scores on his or her test are consistent and whether the content of the test is compatible with the 
objectives of the class and the materials used. For example, teachers are encouraged to learn how to use the statistical formula-the Kude-Richardson formula 21 (K-R21) - to measure the dependability of the scores on their test.

In addition to this theoretical and technical knowledge of language assessment, EFL teachers need to be introduced to the different stages involved in developing and designing a language test. O'Sullivan (2012) refers to a model of test development produced by ESOL in Cambridge. The model comprises a total of nine steps, starting with a perceived need for a test and ending in revision. Four of the steps are the planning, designing, development, and operational phases. While this model was originally developed for the designing of major tests, it can be incorporated by classroom teachers who want to produce their own classroom tests.

The critical element of assessment literacy will also need to be introduced as an important part of a teacher's education. Testing courses need to consider the following points:

Ethics of language testing and a challenge to the presumed neutrality of measurement procedures Tests are often assumed to be fair and bias free. However, testing students is a major responsibility and instruments need to be checked in order to make sure that they do not advantage a group of students over another on the basis of issues of background, educational experience, and familiarity of content.

Testers' responsibilities This issue needs to be debated, because tests can be used for purposes other than their intended uses, for example to decide on immigration quotas or on a person's employability.

Learners' rights Learners need to have a voice in the process of testing. They have the right to receive feedback, retake a test for various reasons, choose the format, or appeal about results.

Consequential validity This is about the effects that a test can have on the lives of learners and on society at large. Tests will determine whether students can have access to university education, and therefore to better employment opportunities. Failure in certain high-stakes tests can have detrimental social effects on the individual. Tests and scores can be manipulated in favor of political decisions that can serve one segment of society at the expense of others.

Teacher educators in teacher-preparation programs will need to bring the attention of prospective teachers to the main theoretical tenets of critical language testing. Without a solid theoretical foundation, teachers' pedagogy might remain unconvincing. Familiarity with the issues discussed in the next two paragraphs will provide teachers with a rationale for adopting a more balanced approach to assessment.

Originally designed to select people for certain positions and functions in society, tests have grown in scope to become powerful tools and are employed to exercise political, social, and educational control (Spolsky, 1997). Critical approaches to testing, which are informed by the critical theory and the main tenets of critical applied linguistics, have ushered in a new era in the research on 
testing and provided different perspectives on the roles of testing in society (Shohamy, 2001, 2013; McNamara \& Roever, 2006). Challenging fundamental assumptions about the goals, intentions, procedures, and principles of language tests, critical approaches to language testing demonstrate how the politics of testing is a major factor in shaping language programs, classroom methodologies, and students' educational experiences. The agenda of critical language testing is therefore to question mainstream approaches to testing by investigating the power and consequences of tests on education and society.

While still in relative infancy, critical language testing approaches have contributed to the literature and knowledge about the powerful and sometimes devastating effects of major stakes tests, about the misuse of tests, and about unethical practices around testing. Accordingly, tests are seen not only as tools designed to measure students' learning, proficiencies, and achievements or to evaluate the quality of the educational curriculum, but as instruments of public control invested with great authority and power. Major tests are often supported by powerful institutions, and their results are regarded as final and unchallengeable. Entry to and graduation from universities and language programs are increasingly based on test scores, and policy makers will use tests to determine cut scores and quotas. Test takers have no choice but to accommodate the conditions and criteria of these tests and force themselves to meet them if they want to have access to educational institutions. In a study aiming to give voice to test takers, Huhta, Kalaja and Pitkänen-Huhta (2006) investigated how students in Norway prepare for a major national test with major language components. A main finding is how complex-and often how very emotional-an experience the test preparation process can be, as students adopt different roles and discourses to cope with the process. Shohamy argues that the authority and power of tests have a strong appeal to the public and in particular to parents, who see them as a measure of how serious the educational system is. Using Bourdieu' notion of symbolic power, Shohamy (2001) suggests that, as powerful tools, tests are exploited by those in power and made to serve their own social and political agendas and to reinforce unequitable social and educational power structures.

SEE ALSO: Assessment Literacy; Assessment development norms; Ethics in Testing and Assessment

\section{References}

Au, W. (2009). Social studies, social justice: W(h)ither the social studies in high-stakes testing? Teacher Education Quarterly, 36(1), 43-58.

Brown, J. D. (1996). Testing in language programs. Upper Saddle River, NJ: Prentice Hall.

Brown, J. D. (2005). Testing in language programmes: A comprehensive guide to English language assessment. New York, NY: McGraw-Hill. 
Brown, J. D., \& Hudson, T. (1998). The alternatives in language assessment. TESOL Quarterly, 32(4), 653-75.

Cheng, L., Rogers, T., \& Wang, X. (2008). Assessment purposes and procedures in ESL/EFL classroom. Assessment and Evaluation in Higher Education, 33, 9-32.

Coombe, C., Troudi, S., \& Al-Hamly, M. (2012). Foreign and second language teacher assessment literacy: Issues, challenges and recommendations. In C. Coombe, P. Davidson, B. O'Sullivan, \& S. Stoynoff (Eds.), The Cambridge guide to language assessment (pp. 20-9). Cambridge, England: Cambridge University Press.

Huhta, A., Kalaja, P., \& Pitkänen-Huhta, A. (2006). Discursive construction of a high-stakes test: the many faces of a test-taker. Language Testing, 23(3), 326-50.

Kunan, A. J. (2010). Test fairness and Toulmin's argument structure. Language Testing, 27(2), 183-9.

Leung, C., \& Mohan, B. (2004). Teacher formative assessment and talk in classroom contexts: Assessment as discourse and assessment of discourse. Language Testing, 21, 335-59.

McNamara, T. (2000). Language testing. Oxford, England: Oxford University Press.

McNamara, T., \& Roever, C. (2006). Language testing: The social dimension. Oxford, England: Wiley Blackwell.

O'Sullivan, B. (2012). The assessment development process. In C. Coombe, P. Davidson, B. O'Sullivan, \& S. Stoynoff (Eds.), The Cambridge guide to language assessment (pp. 47-58). Cambridge, England: Cambridge University Press.

Popham, W. J. (2004). All about accountability: Why assessment illiteracy is professional suicide. Educational Leadership, 62(1), 82-3.

Shohamy, E. (2001). The power of tests: A critical perspective on the uses of language tests. London, England: Longman.

Shohamy E. (2013). The discourse of language testing as a tool for shaping national, global, and transnational identities. Language and Intercultural Communication, 13(2), 225-36.

Spolsky, B. (1997). The ethics of gatekeeping tests: What have we learned in a hundred years? Language Testing, 14(3), 242-7.

Troudi, S., Coombe, C., \& Al-Hamly, M. (2009). EFL teachers' views of English language assessment in higher education in the United Arab Emirates and Kuwait. TESOL Quarterly, 43(3), 546-55.

\section{Suggested Readings}

Brown, A. (2012). Ethics in language testing and assessment. In C. Coombe, P. Davidson, B. O'Sullivan, \& S. Stoynoff (Eds.), The Cambridge guide to language assessment (pp. 113-21). Cambridge, England: Cambridge University Press.

Brown, J. D. (2012). What teachers need to know about test analysis. In C. Coombe, P. Davidson, B. O'Sullivan, \& S. Stoynoff (Eds.), The Cambridge guide to language assessment (pp. 105-12). Cambridge, England: Cambridge University Press. 
Please note that the abstract and keywords will not be included in the printed book, but are required for the online presentation of this book which will be published on Wiley's own online publishing platform.

If the abstract and keywords are not present below, please take this opportunity to add them now.

The abstract should be a short paragraph upto 200 words in length and keywords between 5 to 10 words.

\begin{abstract}
This entry addresses the nature of EFL/ESL teacher's assessment literacy. The focus is on the elements that need to constitute teacher's knowledge about language assessment. In addition to theoretical, technical, and procedural considerations, teachers need to know about the politics of testing and the effect tests have on individuals and society. A balance between technicality and criticality is needed for teachers to develop an informed and critical approach to language testing.
\end{abstract}

\title{
KEYWORDS
}

assessment methods in applied linguistics, critical language testing, ethics of testing, politics of assessment, teacher assessment literacy 


\section{Author Query}

AQ1 Please can you check and let us know if you are fine with your affiliation as listed below or would you like to update the affiliation.

Salah Troudi: Graduate School of Education, University of Exeter, UK. 